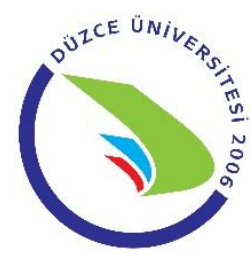

\title{
Bipolar Bozukluk Hastalarında Çocukluk Çağı Travması ile Bilişsel Duygu Düzenleme ve Başa Çıkma Tutumları Arasındaki İlişki
}

\author{
Taha Can TUMAN 國 ${ }^{1}$, Onur HURŞİTOĞLU ${ }^{2}{ }^{2}$,
}

\section{öz}

Amaç: Bu çalışmada bipolar bozukluk hastalarında çocukluk çağı travması varlığı ve çocukluk çağı travmasının bilişsel duygu düzenleme ve başa çıkma tutumları ile ilişkisinin araştırılması amaçlanmıştır.

Gereç ve Yöntemler: Bu çalışmaya Temmuz 2020 ve Ocak 2021 tarihleri arasında Medipol Üniversitesi Esenler Hastanesine başvuran DSM-5 kriterlerine göre Bipolar bozukluk tanısı konmuş ve halen remisyonda olan 60 hasta dahil edilmiştir. Veriler sosyodemografik veri formu, Çocukluk çağı travma ölçeği (ÇÇTÖ), Bilişsel Duygu Düzenleme Ölçeği ve Başa Çıkma Tutumları Ölçeği (COPE) kullanılarak elde edilmiştir. Veriler Mann Whitney u testi, ki-kare testi ve Spearman korelasyon testi ile değerlendirilmiştir.

Bulgular: Hastaların ortalama yaşları 36,97 $\pm 10,36$ idi. Hastaların çocukluk çağı travma ölçek toplam puanı ortalama 45,82 $\pm 12,97$ idi. Hastaların \%76.6 (n=46)' sında ÇÇTÖ puanı 35 ve üstünde saptandı. Çocukluk çağı travması olan bipolar bozukluk hastalarında, kendini suçlama belirgin olarak yüksek, duygusal odaklı başa çıkma belirgin olarak düşük saptandı. Ayrıca bipolar bozukluk hastalarında çocukluk çağı travması varlığı ile kendini suçlama ve diğerlerini suçlama arasında pozitif yönde anlamlı ilişki, olumlu yeniden değerlendirme ve pozitif yeniden yorumlama ile negatif yönde anlamlı ilişki saptandı.

Sonuç: Bipolar bozukluk hastalarında yüksek oranda çocukluk çağı travması bulunduğu ve çocukluk çağı travmasının bazı bilişsel duygu düzenleme ve başa çıkma tutumlarını etkilediği belirlenmiştir.

Anahtar Kelimeler: Bipolar; çocukluk çağı travması; başa çıkma; bilişsel duygu düzenleme.

\section{Childhood Trauma, Cognitive Emotion Regulation and Coping Attitudes in Patients with Bipolar Disorder}

\begin{abstract}
Aim: In this study, it was aimed to investigate the relationship between the presence of childhood trauma and childhood trauma with cognitive emotion regulation and coping attitudes in bipolar disorder patients.

Material and Methods: In this study, 60 patients who were diagnosed with Bipolar affective disorder according to DSM-5 criteria and who were still in remission between July 2020 and January 2021 were included in the Medipol University Esenler Hospital. The data were obtained using the sociodemographic data form, the Childhood Trauma Scale (CTQ), the Cognitive Emotion Regulation Scale, and the Coping Attitudes Scale (COPE). The data were evaluated with the Mann Whitney u test, the chi-square test and the Spearman correlation test.

Results: The mean age of the patients was 36,97 $\pm 10,36$ years. The mean childhood trauma scale score of the patients was $45,82 \pm 12,97$. CTQ score was found 35 and above in $76.6 \%(n=46)$ of the patients. Self-blame was significantly higher and emotionally focused coping was significantly lower in bipolar patients with childhood trauma. In addition, a positive significant relationship was found between the presence of childhood trauma and self-blame and blaming others, and a negative significant relationship with positive re-evaluation and positive reinterpretation in patients with bipolar disorder.

Conclusion: It has been determined that bipolar disorder patients have a high rate of childhood trauma and childhood trauma affects some cognitive emotion regulation and coping attitudes.
\end{abstract}

Keywords: Bipolar; childhood trauma; coping attitudes; cognitive emotion regulation.

1 Medipol University, Medical Faculty, Department of Psychiatry, İstanbul, Türkiye

2 Necip Fazıl State Hospital, Department of Psychiatry, Kahramanmaraş, Türkiye 


\section{GIRIŞ}

Bipolar bozukluk, manik, hipomanik ve depresif epizotlarla karakterize, arada rezidüel belirtilerin devam ettiği ya da tam iyileşmenin olduğu ötimik dönemlerle seyreden, günlük yaşam aktivitelerini ve işlevselliği önemli ölçüde etkileyen bir duygudurum bozukluğudur (1). Bipolar bozukluk, nüfusun yaklaşık olarak \%1'ini etkiler ve uzun vadeli bilişsel ve psikolojik bozukluklara yol açar. Ayrıca toplum üzerinde ağır ekonomik ve sosyal yüklere neden olur (2). Bipolar bozukluğun gelişiminde Bipolar bozukluk, tipik olarak $15-25$ yaşa arasında ergenlik ve erken erişkinlik döneminde başlar. Bipolar bozukluk gelişiminde biyolojik, genetik ve çevresel faktörlerin ve bu faktörler arasındaki etkileşimin rol oynadığ 1 düşünülmektedir (3). Bu çevresel faktörlerden bir tanesi de çocukluk çăğ travmasıdır (4).

Çocukluk çağı travması, genellikle çocuğun bakımından ve korunmasından sorumlu ebeveyn ya da diğer erişkinlerden kaynaklanan, çocuğun fiziksel, psikolojik, cinsel ya da sosyal hasarı sonucu ihmal edilmesi olarak tanımlanır (5). Duygusal, fiziksel ve cinsel istismar, duygusal ve fiziksel ihmal, çocukluk çağında görülen travmalardır (6). Çocukluk çağı travma öyküsü, başta anksiyete bozukluğu, depresif bozukluklar, kişilik bozukluğu, travma sonrası stres bozukluğu ve alkol madde kullanım bozuklukları olmak üzere birçok psikiyatrik hastalıkla ilişkili bulunmuştur (4). Çocukluk çağı travmaları, psikiyatrik hastalıklar için biyolojik, genetik yatkınlık faktörlerine sahip kişilerde, hastalığın ortaya çıkışını ya da gidişatını etkileyebilir (7). Aynı zamanda çocukluk çağı travmaları, hipotalamo-pitüiteradrenal aksı tetikleyerek, bipolar bozuklukta bilişsel ya da davranışsal süreçleri ilgilendiren beyin bölgelerini etkileyebilir (8). Çocukluk çağı travmasına maruz kalmak, mevcut nöroplastik adaptasyon potansiyelini inhibe etmektedir ve nörogelişimin hassas olduğu dönemlerde nöral ağların gelişimini olumsuz etkilemektedir (9).

Başa çıkma tutumları, stresli olarak değerlendirilecek durumları yönetmek için kullanılan bilişsel ve davranışsal çabalar olarak tanımlanır (10). Lazarus tarafından geliştirilen bu kavram, bireye özgü niteliktedir, ancak statik değildir ve gelişiminde birçok genetik ve çevresel faktör rol oynamaktadır (11). Başa çıkma becerilerinin tutumlarının zayıflığı, azalmış psikolojik iyilik hali ve bozulmuş sosyal işlevsellikle ilişkilidir (12).

Bilişsel duygu düzenleme, kişinin günlük yaşam olayları ve stresli durumlarda duygularını yönetme ve bunun için kullandıkları başa çıkma stratejileri olarak tanımlanır. Bilişsel duygu düzenleme, iyilik hali ve sosyal işlevselliği sağlamakta önemli bir rol oynamaktadır. Bilişsel duygu düzenleme, diğer başa çıkma boyutları ile ilişkilidir. Stresli yaşam olayları karşısında bireyin başvurduğu başa çıkma yollarıdır. Bilişsel süreçler, stres ve stresli durumlarda duyguları yönetmeye, düzenlemeye ve duyguları kontrol etmeye ve bunlardan etkilenmemeye yardımcı olabilir (13).

Bipolar bozukluk, yaşam boyu devam eden ve önemli sosyal ve mesleki işlev bozukluğu oluşturan bir hastalıktır (2). Bipolar bozuklukta hastalığın gelişmesinde, sürmesinde ve gidişatında aracılık eden faktörlerin tanınmasının hastaların yaşam kalitesinin artmasında faydalı olacağını düşünüyoruz. Bu çalışmada bipolar bozukluk hastalarında çocukluk çağı travması, başa çıkma tutumları ve bilişsel duygu düzenleme bozukluğunun varlığını belirlenmesi ve çocukluk çağı travmaları ile başa çıkma tutumları ve bilişsel duygu düzenleme stratejileri arasındaki ilişkinin değerlendirilmesi amaçlanmaktadır.

\section{GEREÇ VE YÖNTEMLER}

Bu çalışmaya Temmuz 2020 ve Ocak 2021 tarihleri arasında Medipol Üniversitesi Esenler Hastanesi psikiyatri polikliniğine başvuran, DSM-5 kriterlerine göre bipolar bozukluk tanısı konmuş, son üç aydır hastanede yatışı olmayan, halen remisyonda olan (YMRS skoru $<8$ ve HAM-D skoru<8), çalışmaya katılmaya gönüllü, okur yazar olan 18-65 yaş arası 60 hasta dahil edildi. Hastaların şizofreni, mental retardasyon, alkol ve madde kullanım bozukluğu, otizm, demans, epilepsi ve kognitif fonksiyonları etkileyen nörolojik hastalığı olan hastalar çalışmadan dışlandı. Tüm katılımcılardan bilgilendirilmiş onam formu alındi.

$\mathrm{Bu}$ çalışma projesi Medipol Üniversitesi Tıp Fakültesi Girişimsel Olmayan Klinik Araştırmalar Etik Kurulu tarafindan onayland 1 (26.06.2020/10840098-604.01.01E.17820). Çalışma verileri hastanede yüz yüze görüşme ile psikiyatrist tarafından toplandı. Bu çalışma, Helsinki deklarasyonunda belirlenen kurallar çerçevesinde yapıldı. Öncelikle hastaların demografik verileri, sigara öyküsü, hastalığın başlangıç yaşı, hastalık süresi, hastaneye yatış sayısı, suisid girişimi öyküsü ve kullanmakta oldukları tedaviler kaydedildi. Ardından çocukluk çağı travma ölçeği, bilişsel duygu düzenleme ölçeği ve başa çıkma tutumları ölçeği özbildirim yöntemi ile uygulandı.

\section{Çocukluk Çaği Travma Ölçeği (ÇÇTö)}

Bernstein ve arkadaşları tarafindan 2003 yilında çocukluk ve ergenlik dönemindeki travma yaşantılarının geriye dönük olarak değerlendirilmesi için likert tipi özbildirim ölçeği olarak geliştirilmiş̧ir (14). Duygusal istismar, fiziksel istismar, cinsel istismar, duygusal ihmal ve fiziksel ihmal olmak üzere 5 alt ölçeği vardır. Türkçe geçerlilik ve güvenilirlik çalışması Şar ve arkadaşları tarafından yapılmıştır. Geçerlilik ve güvenilirlik çalışmasında cinsel ve fiziksel istismar için 5 puan üzeri, fiziksel ihmal ve duygusal istismar için 7 puan üzeri, duygusal ihmal için 12 puan üzeri, toplam ölçek skoru için ise 35 puan üzeri anlamlı kabul edilmesi önerilmiştir. Cronbach alfa değeri 0.93 olarak bulunmuştur. (15).

\section{Başa Çıkma Tutumlarını Değerlendirme Ölçeği (COPE)}

İnsanların günlük yaşamlarında güç veya bunaltı verici olaylarla ya da sorunlarla karşılaştıkları zaman nasıl tepki verdiklerini değerlendirmek amacıyla Carver ve arkadaşları tarafından geliştirilmiş 60 sorudan oluşan 4 lü likert tipi öz-bildirim ölçeğidir (16). Ağargün ve arkadaşları tarafından Türkçeye çevrilmiş ve geçerlilik güvenilirlik çalışması yapılmış olup, cronbach alfa değeri 0.79 olarak bulunmuştur. Soruna odaklı başa çıkma, duygusal odaklı başa çıkma ve işlevsel olmayan başa çıkma olmak üzere üç ana bölümden oluşmaktadır. Üç ana bölümün her biri beşer alt ölçekten oluşmaktadır. Alt ölçeklerden alınan puanların yüksekliği, hangi başa çıkma tutumunun kişi tarafından daha çok kullanıldığı hakkında bilgi verir (17).

Bilişsel Duygu Düzenleme Ölçeği (CERQ) 
Garnefski ve arkadaşları tarafından geliştirilmiş olup olumsuz yaşam deneyimleri ile karşılaştıktan sonra kişilerin farklı duygu düzenleme stratejileri kullanımını değerlendirir (18). Ölçek, beşli likert tipi olup, dokuz alt ölçek (ruminasyon, olumlu yeniden odaklanma, olumlu yeniden değerlendirme, perspektif içine alma, planlamaya yeniden odaklanma, felaketleştirme, kabul, diğerlerini suçlama ve kendini suçlama), her alt ölçekte 4 madde ve toplam 36 maddeden oluşmaktadır. Kendini suçlama, diğerlerini suçlama, ruminasyon ve felaketleştirmeyi uyumsuz başa çıkma stratejileri olarak görürken; kabul, planlamaya yeniden odaklanma, olumlu yeniden odaklanma, olumlu yeniden değerlendirme ve olayın değerini azaltma stratejilerini uyumlu stratejiler olarak belirlenmiştir. Ölçeğin Türkçe geçerlilik güvenirlilik çalışması Ataman tarafından 2011 yılında yapılmıştır (19).

\section{İstatistiksel Analiz}

İstatistiksel analiz SPSS for Windows 24.0 sürümü ile yapıldı ve $\mathrm{p}$ değeri $<0.05$ istatistiksel olarak anlamlı kabul edildi. Tanımlayıcı istatistikler sayısal değişkenler için ortalama \pm standart sapma, kategorik değişkenler için frekans değerleri olarak ifade edildi. Sayısal değişkenlerin normalliği Shaphiro-Wilk testi ile değerlendirildi. Normal olmayan sayısal değişkenler için 2 grubu karşılaştırmak için Mann Whitney U testi uygulandı. Kategorik değişkenler ki-kare testi ile değerlendirildi. Sayısal değişkenler arasındaki ilişkilerin belirlenmesinde Spearman korelasyon katsayısı kullanıldı. Ayarlanmış regresyon katsayılarını ve olasılık oranlarını ve \% 95 güven aralıklarını tahmin etmek için çok değişkenli doğrusal ve ikili lojistik regresyon analizi yapıldı. Çoklu bağlantıya ilişkin değerlendirmeler için VIF (Variance inflation factor) değerleri hesaplandı.

\section{BULGULAR}

$\mathrm{Bu}$ çalışma 20-63 yaş aralığında remisyonda olan 60 bipolar bozukluk hastasını içermektedir. Hastaların ortalama yaşları 36,97 $\pm 10,36$ idi. Hastaların 36'sı (\%60) erkek, 24'ü (\%40) kadındı. Hastaların ortalama hastalık süresi $11,07 \pm 8,07$ idi. Hastalığın başlangıç yaşı ortalama 25,9 \pm 7,76 idi. Bipolar bozukluk nedeniyle ortalama hastaneye yatış sayısı 2,8 $\pm 2,84$ idi. Hastaların $\% 13,3$ 'ü $(\mathrm{n}=8)$ yalnızca antipsikotik, \%23,3'ü $(\mathrm{n}=14)$ yalnızca duygudurum düzenleyici, \%63,3'ü $\quad(n=38) \quad$ ise duygudurum düzenleyici ve antipsikotik tedaviyi birlikte kullaniyordu. Hastaların demografik ve klinik verileri (yaş, cinsiyet, medeni durum, eğitim, çalışıp çalışmadığı, kullandığı tedavi çeşidi, intihar girişimi öyküsü, hastanede yatış sayısı, hastalığın başlangıç yaşı) Tablo 1 'de gösterilmiştir.

Bipolar bozukluk hastalarının çocukluk çağı travma ölçeği skorları incelendiğinde, çocukluk çağı travma ölçeği toplam puan ortalaması 45,82 $\pm 12,97$ idi. Alt ölçek puan ortalamaları ise sırasıyla duygusal istismar için 9,25 $\pm 4,48$, fiziksel istismar için 7,27 $\pm 3,89$, cinsel istismar için $6,57 \pm 2,63$, fiziksel ihmal için 8,45 $\pm 3,19$, duygusal ihmal için 14,28 \pm 5,63 idi (Tablo 2).

Bipolar hastaların bilişsel duygu düzenleme ölçeğinin alt ölçeklerinden aldıkları puan ortalamaları; kendini suçlama 11,22 $\pm 4,01$, diğerlerini suçlama 9,82 $\pm 3,87$, ruminasyon $13,22 \pm 3,84$, felaketleştirme $10,98 \pm 4,55$, kabul $11,32 \pm 2,95$, plan yapmaya yeniden odaklanma $12,15 \pm 4,12$,

olumlu yeniden odaklanma $10,48 \pm 4,39$, olumlu yeniden değerlendirme $11,87 \pm 4,47$, olayın değerini azaltma stratejileri 12,07 \pm 3,66 şeklindedir (Tablo 3).

Tablo 1. Hastaların sosyodemografik ve klinik özellikleri

\begin{tabular}{|c|c|c|}
\hline & \multicolumn{2}{|c|}{ Tanımlayıcı İstatistikler $(\mathrm{n}=\mathbf{6 0})$} \\
\hline & $\mathbf{n}$ & $\%$ \\
\hline \multicolumn{3}{|l|}{ Cinsiyet } \\
\hline Erkek & 36 & 60,0 \\
\hline Kadın & 24 & 40,0 \\
\hline \multicolumn{3}{|l|}{ Eğitim } \\
\hline İlköğretim & 12 & 20,0 \\
\hline Lise & 29 & 48,3 \\
\hline Üniversite & 19 & 31,7 \\
\hline \multicolumn{3}{|l|}{ Meslek } \\
\hline Çalışıyor & 25 & 41,7 \\
\hline Çalışmiyor & 27 & 45,0 \\
\hline Emekli & 8 & 13,3 \\
\hline \multicolumn{3}{|l|}{$\begin{array}{l}\text { Medeni } \\
\text { durum }\end{array}$} \\
\hline Evli & 34 & 56,7 \\
\hline Bekar & 24 & 40,0 \\
\hline Boşanmış & 2 & 3,3 \\
\hline \multicolumn{3}{|l|}{ Sigara } \\
\hline Kullaniyor & 33 & 55,0 \\
\hline Kullanmiyor & 27 & 45,0 \\
\hline \multicolumn{3}{|l|}{$\begin{array}{l}\text { İntihar } \\
\text { girişimi }\end{array}$} \\
\hline Var & 15 & 25,0 \\
\hline Yok & 45 & 75,0 \\
\hline \multicolumn{3}{|l|}{ Tedavi } \\
\hline AP & 8 & 13,3 \\
\hline DDD & 14 & 23,3 \\
\hline \multirow[t]{2}{*}{$\mathrm{AP}+\mathrm{DDD}$} & 38 & 63,3 \\
\hline & Ortalama \pm SS & $\begin{array}{c}\text { Ortanca } \\
\text { (Min-Max) }\end{array}$ \\
\hline Yaş & $36,97 \pm 10,36$ & $36,5(20-63)$ \\
\hline Hastalık süresi & $11,07 \pm 8,07$ & $8,5(2-36)$ \\
\hline Başlangıç yası & $25,9 \pm 7,76$ & $24(16-50)$ \\
\hline Hastane yatış & $2,8 \pm 2,84$ & $2(0-14)$ \\
\hline
\end{tabular}


(AP: Antipsikotik, DDD: Duygudurum düzenleyici, SS: Standart sapma, Min: Minimum, Max: Maksimum)

Tablo 2. Hastaların çocukluk çağı travma ölçeği puanları

\begin{tabular}{|l|l|l|}
\hline & \multicolumn{2}{|c|}{ Tanımlayıcı İstatistikler (n=60) } \\
\hline Ölçekler & Ortalama \pm SS & $\begin{array}{l}\text { Ortanca } \\
\text { Max) }\end{array}$ \\
\hline ÇÇTÖ Toplam & $45,82 \pm 12,97$ & $44,5(25-86)$ \\
\hline $\begin{array}{l}\text { Duygusal } \\
\text { istismar }\end{array}$ & $9,25 \pm 4,48$ & $7,5(5-20)$ \\
\hline Fiziksel istismar & $7,27 \pm 3,89$ & $5(5-24)$ \\
\hline Fiziksel ihmal & $8,45 \pm 3,19$ & $8(5-19)$ \\
\hline Duygusal ihmal & $14,28 \pm 5,63$ & $13,5(5-25)$ \\
\hline Cinsel istismar & $6,57 \pm 2,63$ & $5(5-16)$ \\
\hline
\end{tabular}

(ÇÇTÖ: Çocukluk çağı travma ölçeği, SS: Standart sapma, Min: Minimum, Max: Maksimum)

Tablo 3. Hastaların bilişsel duygu düzenleme ölçeği puanlar1

\begin{tabular}{|l|c|c|}
\hline & \multicolumn{2}{|c|}{ Tanımlayıcı İstatistikler (n=60) } \\
\hline Ölçekler & $\begin{array}{c}\text { Ortalama } \\
\text { SS }\end{array}$ & $\begin{array}{c}\text { Ortanca (Min- } \\
\text { Max) }\end{array}$ \\
\hline $\begin{array}{l}\text { Bilişsel duygu } \\
\text { düzenleme ölçeği }\end{array}$ & & \\
\hline Kendini suçlama & $11,22 \pm 4,01$ & $11(4-20)$ \\
\hline Diğerlerini suçlama & $9,82 \pm 3,87$ & $8(4-18)$ \\
\hline Ruminasyon & $13,22 \pm 3,84$ & $13(6-20)$ \\
\hline Felaketleştirme & $10,98 \pm 4,55$ & $9.5(4-20)$ \\
\hline Kabul & $11,32 \pm 2,95$ & $11(5-17)$ \\
\hline $\begin{array}{l}\text { Plan yapmaya } \\
\text { yeniden odaklanma }\end{array}$ & $12,15 \pm 4,12$ & $12(5-20)$ \\
\hline $\begin{array}{l}\text { Olumlu yeniden } \\
\text { odaklanma }\end{array}$ & $10,48 \pm 4,39$ & $9(4-20)$ \\
\hline $\begin{array}{l}\text { Olumlu yeniden } \\
\text { değerlendirme }\end{array}$ & $11,87 \pm 4,47$ & $12(5-20)$ \\
\hline $\begin{array}{l}\text { Olayın değerini } \\
\text { azaltma stratejileri }\end{array}$ & $12,07 \pm 3,66$ & $12(6-20)$ \\
\hline & & \\
\hline
\end{tabular}

(SS: Standart sapma, Min: Minimum, Max: Maksimum)

Hastaların başa çıkma tutumları ölçeğinin ana bölümünden aldıkları ortalamaları; işlevsel olmayan başa çıkma 46,82 $\pm 11,44$, duygusal odaklı başa çıkma 56,93 \pm 9,74 ve sorun odaklı başa çıkma 53,63 \pm 9,93 şeklindedir. Alt ölçek puanları Tablo 4'te belirtilmiştir.

Bipolar bozukluk hastalarının çocukluk çağı travması skorlarına göre ÇÇTÖ $<35$ ve ÇÇTÖ $\geq 35$ olarak iki gruba ayrılıp klinik özellikleri ve bilişsel duygu düzenleme puanları açısından karşılaştırıldığında, hastalık süresi, hastaneye yatış, hastalığın başlangıç yaşı açısından istatistiksel olarak anlamlı fark saptanmadı. Kendini suçlama alt ölçek puan ortalaması, ÇÇTÖ $\geq 35$ olan grupta, ÇÇTÖ <35 grubuna göre istatistiksel olarak anlamlı düzeyde yüksek bulundu $(\mathrm{p}=0,016)$ (Tablo 5).
Tablo 4. Hastaların başa çıkma tutumları ölçeği puanları

\begin{tabular}{|c|c|c|}
\hline \multirow[b]{2}{*}{ Ölçekler } & \multicolumn{2}{|c|}{ Tanımlayıcı İstatistikler $(n=60)$} \\
\hline & Ortalama \pm SS & $\begin{array}{c}\text { Ortanca } \\
\text { (Min-Max) }\end{array}$ \\
\hline $\begin{array}{l}\text { İşlevsel olmayan } \\
\text { başa çıkma }\end{array}$ & $46,82 \pm 11,44$ & $46(21-99)$ \\
\hline $\begin{array}{l}\text { Davranışsal } \\
\text { boşverme }\end{array}$ & $10,07 \pm 6,49$ & $9(4-53)$ \\
\hline Zihinsel boşverme & $9,93 \pm 2,9$ & $10(4-15)$ \\
\hline Madde kullanımı & $6,07 \pm 3,32$ & $4(4-16)$ \\
\hline $\begin{array}{l}\text { Duruma } \\
\text { odaklanma }\end{array}$ & $11,98 \pm 2,84$ & $12.5(5-16)$ \\
\hline İnkar & $8,77 \pm 3,19$ & $8(4-15)$ \\
\hline $\begin{array}{l}\text { Duygusal odaklı } \\
\text { başa çıkma }\end{array}$ & $56,93 \pm 9,74$ & $57(36-75)$ \\
\hline $\begin{array}{l}\text { Duygusal sosyal } \\
\text { destek kullanımı }\end{array}$ & $11,35 \pm 2,79$ & $12(5-16)$ \\
\hline $\begin{array}{l}\text { Pozitif yeniden } \\
\text { yorumlama }\end{array}$ & $11,8 \pm 3,02$ & $12(4-16)$ \\
\hline Dini başa çıkma & $13,68 \pm 2,76$ & $14.5(4-16)$ \\
\hline Kabullenme & $11,5 \pm 2,79$ & $12(4-16)$ \\
\hline Şaka yapma & $8,6 \pm 4,39$ & $8(4-28)$ \\
\hline $\begin{array}{l}\text { Sorun odaklı } \\
\text { başa çıkma }\end{array}$ & $53,63 \pm 9,93$ & $53(33-76)$ \\
\hline Aktif başa çıkma & $10,78 \pm 3,1$ & $11(4-16)$ \\
\hline Planlama & $11,37 \pm 2,96$ & $11(6-16)$ \\
\hline $\begin{array}{l}\text { Yararlı sosyal } \\
\text { destek kullanımı }\end{array}$ & $11,27 \pm 3,38$ & $11(4-16)$ \\
\hline $\begin{array}{l}\text { Diğer } \\
\text { meşguliyetleri } \\
\text { bastırma }\end{array}$ & $10,43 \pm 2,63$ & $10(4-16)$ \\
\hline Geri durma & $9,78 \pm 2,43$ & $10(4-15)$ \\
\hline
\end{tabular}

(SS: Standart sapma, Min: Minimum, Max: Maksimum)

Bipolar bozukluk hastalarının \%76.6'sında $(n=46)$ ÇÇTÖ puanı 35 ve üstünde saptandı. ÇÇTÖ $<35$ ve ÇÇTÖ $\geq 35$ olarak gruplar başa çıkma tutumları açısından karşılaştırıldığında; duygusal odaklı başa çıkma ve geri durma puan ortalamaları, ÇÇTÖ $\geq 35$ olan grupta ÇÇTÖ $<$ 35 olan gruba göre istatistiksel olarak anlamlı düzeyde düşük bulundu ( $p$ değerleri sirasıyla $p=0,039, p=0,013$ ) (Tablo 6). 
Tablo 5. Çocukluk çağı travma puanları $35^{\prime}$ in altında ve 35 ve üstünde olan grubun klinik özellikleri ve bilişsel duygu düzenleme puanlarının karşılaştırılması

\begin{tabular}{|c|c|c|c|}
\hline & \multicolumn{2}{|c|}{$\begin{array}{l}\text { Çocukluk Çağı Travması } \\
\text { Ölçeği Toplam Puanı }\end{array}$} & \multirow[b]{2}{*}{$\mathbf{P}$} \\
\hline & $\begin{array}{c}<35 \quad(\mathrm{n}=14 \\
\text { (1) }\end{array}$ & $\geq 35 \quad(n=46)$ & \\
\hline & \begin{tabular}{|c|} 
Ortanca \\
$(\% 25-\% 75)$ \\
\end{tabular} & $\begin{array}{c}\text { Ortanca } \\
(\% 25-\% 75) \\
\end{array}$ & \\
\hline ÇÇTÖ Toplam & $30,5(29-34)$ & $48(42-56)$ & 0.001 \\
\hline Hastalık süresi & $6(5-10)$ & $9(6-15)$ & 0,210 \\
\hline Başlangıç yası & $23,5(21-27)$ & $24,5(20-29)$ & 0,902 \\
\hline Hastane yatış & $2(1-4)$ & $2(1-4)$ & 0,993 \\
\hline $\begin{array}{l}\text { Kendini } \\
\text { suçlama }\end{array}$ & $9(8-10)$ & $11(9-14)$ & $0,016^{*}$ \\
\hline $\begin{array}{l}\text { Diğerlerini } \\
\text { suçlama }\end{array}$ & $8(7-8)$ & $9(8-14)$ & 0,062 \\
\hline Ruminasyon & $12,5(10-13)$ & $13(11-17)$ & 0,257 \\
\hline Felaketleştirme & $9(7-9)$ & $11(8-15)$ & 0,075 \\
\hline Kabul & $12(10-12)$ & $11(9-14)$ & 0,434 \\
\hline $\begin{array}{l}\text { Plan yapmaya } \\
\text { yenıden } \\
\text { odaklanma }\end{array}$ & $12,5(10-15)$ & $12(8-15)$ & 0,440 \\
\hline $\begin{array}{l}\text { Olumlu } \\
\text { yeniden } \\
\text { odaklanma } \\
\end{array}$ & $9,5(8-12)$ & $9(7-15)$ & 0,854 \\
\hline $\begin{array}{l}\text { Olumlu } \\
\text { yeniden } \\
\text { değerlendirme }\end{array}$ & $13,5(9-15)$ & $12(7-15)$ & 0,344 \\
\hline $\begin{array}{l}\text { Olayın } \\
\text { değerini } \\
\text { azaltma } \\
\text { stratejılerı }\end{array}$ & $11,5(11-14)$ & $12,5(8-15)$ & 0,874 \\
\hline
\end{tabular}

Bipolar bozukluk hastalarında çocukluk çağı travma toplam puanları ve alt ölçek puanları ile bilişsel duygu düzenleme puanlarının korelasyon analizlerine bakıldığında, çocukluk çağı travma toplam puanları ile kendini suçlama $(\mathrm{r}=0,313 ; \mathrm{p}=0,015)$ ve diğerlerini suçlama $(r=0,264 ; p=0,041)$ alt ölçek puanları arasında pozitif yönde düşük dereceli, olumlu yeniden değerlendirme $(r=-0,274 ; p=0,034)$ alt ölçek puanı ile negatif yönde düşük dereceli anlamlı ilişki saptandı. Duygusal istismar puanları ile ruminasyon $(\mathrm{r}=0,311$; $\mathrm{p}=0,016)$ ve felaketleştirme $(\mathrm{r}=0,287 ; \mathrm{p}=0,026)$ alt ölçek puanları arasında pozitif yönde düşük dereceli, kendini suçlama $(r=0,422 ; p=0,001)$ alt ölçek puanı ile pozitif yönde orta dereceli, olumlu yeniden değerlendirme $(r=-$ 0,$314 ; p=0,014$ ) alt ölçek puanı ile negatif yönde düşük dereceli anlamlı ilişki saptandı. Fiziksel istismar puanları ile kendini suçlama $(r=0,266 ; p=0,040)$ alt ölçek puanı arasında pozitif yönde düşük dereceli anlamlı ilişki saptandı. Cinsel istismar puanları ile diğerlerini suçlama $(\mathrm{r}=0,334 ; \mathrm{p}=0,009)$, ruminasyon $(\mathrm{r}=0,272 ; \mathrm{p}=0,035)$ ve felaketleştirme $(r=0,283 ; p=0,028)$ alt ölçek puanları arasında pozitif yönde düşük dereceli anlamlı ilişki saptand.

Bipolar hastaların, çocukluk çağı travma puanları ile başa çıkma tutumları puanlarının korelasyon analizlerine bakıldığında, çocukluk çağı travma toplam puanları ile pozitif yeniden yorumlama $(r=-0,323 ; p=0,012)$ alt ölçek puanı arasında negatif yönde düşük dereceli anlamlı ilişki, duygusal istismar puanları ile pozitif yeniden yorumlama $(r=-0,454 ; p<0,001)$ alt ölçek puanı arasında negatif yönde orta, duygusal odaklı başa çıkma $(r=-0,261$; $\mathrm{p}=0,044$ ) puanları arasında negatif yönde düşük dereceli anlamlı ilişki, fiziksel istismar puanları ile madde kullanımı ( $\mathrm{r}=0,276 ; \mathrm{p}=0,033)$ alt ölçek puanı arasında pozitif yönde düşük dereceli anlamlı ilişki, cinsel istismar puanları ile diğer meşguliyetleri bastırma $(r=0,431$; $\mathrm{p}=0,001)$ alt ölçek puanı arasında pozitif yönde orta dereceli anlamlı ilişki saptandı (Tablo 7).

Tablo 6. Çocukluk çağı travma puanları $35^{\text {'in }}$ altında olanlar ve 35 ve $35^{\prime}$ in üstünde olan grubun başa çıkma tutumlarının karşılaştırılması

\begin{tabular}{|c|c|c|c|}
\hline & \multicolumn{2}{|c|}{$\begin{array}{l}\text { Çocukluk Çağı Travması } \\
\text { Ölçeği Toplam Puanı }\end{array}$} & \multirow[b]{2}{*}{$\mathbf{P}$} \\
\hline & $<35(\mathrm{n}=14)$ & $\geq 35 \quad(n=46)$ & \\
\hline & $\begin{array}{c}\text { Ortanca } \\
(\% 25-\% 75)\end{array}$ & $\begin{array}{c}\text { Ortanca } \\
(\% 25-\% 75)\end{array}$ & \\
\hline $\begin{array}{l}\text { Davranışsal } \\
\text { boşverme }\end{array}$ & $10(8-13)$ & $9(7-12)$ & 0,090 \\
\hline $\begin{array}{l}\text { Zihinsel } \\
\text { boşverme }\end{array}$ & $10,5(8-14)$ & $10(7-12)$ & 0,273 \\
\hline Madde kullanımı & $4(4-6)$ & $4(4-8)$ & 0,573 \\
\hline $\begin{array}{l}\text { Duruma } \\
\text { odaklanma }\end{array}$ & $11(10-13)$ & $13(11-14)$ & 0,248 \\
\hline İnkar & $8,5(7-11)$ & $8(6-11)$ & 0,923 \\
\hline $\begin{array}{l}\text { İşlevsel olmayan } \\
\text { başa çıkma }\end{array}$ & $46,5(40-57)$ & $46(41-52)$ & 0,687 \\
\hline $\begin{array}{l}\text { Duygusal sosyal } \\
\text { destek kullanımı }\end{array}$ & $11(10-13)$ & $12(9-14)$ & 0,758 \\
\hline $\begin{array}{l}\text { Pozitif yeniden } \\
\text { yorumlama }\end{array}$ & $13(12-15)$ & $11,5(10-14)$ & 0,057 \\
\hline Dini başa çıma & $15(12-16)$ & $14(12-16)$ & 0,367 \\
\hline Kabullenme & $12(12-14)$ & $11(9-13)$ & 0,104 \\
\hline Şaka yapma & $10,5(7-13)$ & $7(5-11)$ & 0,071 \\
\hline $\begin{array}{l}\text { Duygusal odaklı } \\
\text { başa çıkma }\end{array}$ & $60(56-65)$ & $53,5(49-64)$ & $0,039^{*}$ \\
\hline Aktif başa çıkma & $11(10-14)$ & $10(9-13)$ & 0,232 \\
\hline Planlama & $12,5(11-15)$ & $11(9-14)$ & 0,133 \\
\hline $\begin{array}{l}\text { Yararlı sosyal } \\
\text { destek kullanımı }\end{array}$ & $11(9-13)$ & $11(9-14)$ & 0,819 \\
\hline $\begin{array}{l}\text { Diğer } \\
\text { meşguliyetleri } \\
\text { bastırma }\end{array}$ & $11(9-13)$ & $10(9-12)$ & 0,718 \\
\hline Geri durma & $10(8-13)$ & $9(7-12)$ & $0,013 *$ \\
\hline $\begin{array}{l}\text { Sorun odaklı başa } \\
\text { çıkma }\end{array}$ & $10,5(8-14)$ & $10(7-12)$ & 0,111 \\
\hline
\end{tabular}

* Mann whitney u test 
Tablo 7. Bipolar Bozukluk Hastalarında Çocukluk Çağı Travma Puanları İle Bilişsel Duygu Düzenleme Ve Başa Çıkma Tutumları Puanlarının Korelasyonu

\begin{tabular}{|c|c|c|c|c|c|c|c|}
\hline & & \multicolumn{6}{|c|}{ Çocukluk Çağı Travması Puanları } \\
\hline & & $\begin{array}{l}\text { ÇÇTÖ } \\
\text { toplam }\end{array}$ & $\begin{array}{c}\text { Duygusal } \\
\text { istismar }\end{array}$ & $\begin{array}{l}\text { Fiziksel } \\
\text { istismar }\end{array}$ & $\begin{array}{c}\text { Fiziksel } \\
\text { ihmal }\end{array}$ & Duygusal ihmal & $\begin{array}{l}\text { Cinsel } \\
\text { istismar }\end{array}$ \\
\hline \multirow[t]{2}{*}{ Hastalık süresi } & $\mathrm{R}$ & 0,150 & $-0,026$ & 0,032 & 0,074 & 0,133 & $-0,031$ \\
\hline & $\mathrm{p}$ & 0,253 & 0,841 & 0,809 & 0,573 & 0,310 & 0,815 \\
\hline \multirow[t]{2}{*}{ Başlangıç yaşı } & $\mathrm{R}$ & $-0,016$ & $-0,108$ & $-0,067$ & 0,171 & $-0,005$ & 0,122 \\
\hline & $\mathrm{p}$ & 0,901 & 0,410 & 0,611 & 0,191 & 0,967 & 0,354 \\
\hline \multirow[t]{2}{*}{ Kendini suçlama } & $\mathrm{R}$ & $0,313^{*}$ & $0,422^{* *}$ & $0,266^{*}$ & 0,140 & 0,053 & 0,252 \\
\hline & $\mathrm{p}$ & 0,015 & 0,001 & 0,040 & 0,285 & 0,689 & 0,052 \\
\hline \multirow[t]{2}{*}{ Diğerlerini suçlama } & $\mathrm{R}$ & $0,264^{*}$ & 0,178 & 0,237 & 0,180 & 0,065 & $0,334^{* *}$ \\
\hline & $\mathrm{p}$ & 0,041 & 0,174 & 0,069 & 0,170 & 0,620 & 0,009 \\
\hline \multirow[t]{2}{*}{ Ruminasyon } & $\mathrm{R}$ & 0,148 & $0,311^{*}$ & 0,204 & 0,052 & $-0,072$ & $0,272^{*}$ \\
\hline & $\mathrm{p}$ & 0,259 & 0,016 & 0,118 & 0,695 & 0,586 & 0,035 \\
\hline \multirow[t]{2}{*}{ Felaketleştirme } & $\mathrm{R}$ & 0,235 & $0,287^{*}$ & 0,247 & 0,096 & 0,081 & $0,283^{*}$ \\
\hline & $\mathrm{p}$ & 0,071 & 0,026 & 0,057 & 0,467 & 0,538 & 0,028 \\
\hline \multirow[t]{2}{*}{ Kabul } & $\mathrm{R}$ & $-0,061$ & $-0,145$ & 0,092 & $-0,034$ & $-0,149$ & 0,141 \\
\hline & $\mathrm{p}$ & 0,646 & 0,268 & 0,485 & 0,799 & 0,254 & 0,282 \\
\hline \multirow[t]{2}{*}{ Plan yapmaya yeniden odaklanma } & $\mathrm{R}$ & $-0,155$ & $-0,224$ & $-0,103$ & $-0,105$ & $-0,122$ & $-0,005$ \\
\hline & $\mathrm{p}$ & 0,236 & 0,085 & 0,432 & 0,424 & 0,354 & 0,970 \\
\hline \multirow[t]{2}{*}{ Olumlu yeniden odaklanma } & $\mathrm{R}$ & $-0,145$ & $-0,184$ & $-0,151$ & 0,036 & $-0,132$ & $-0,089$ \\
\hline & $\mathrm{p}$ & 0,270 & 0,159 & 0,248 & 0,787 & 0,314 & 0,498 \\
\hline \multirow[t]{2}{*}{ Olumlu yeniden değerlendirme } & $\mathrm{R}$ & $-0,274^{*}$ & $-0,314^{*}$ & $-0,080$ & $-0,247$ & $-0,223$ & 0,042 \\
\hline & $\mathrm{p}$ & 0,034 & 0,014 & 0,543 & 0,057 & 0,087 & 0,753 \\
\hline \multirow[t]{2}{*}{ Olayın değerini azaltma stratejileri } & $\mathrm{R}$ & $-0,103$ & $-0,140$ & 0,119 & $-0,016$ & $-0,209$ & $-0,137$ \\
\hline & $\mathrm{p}$ & 0,436 & 0,287 & 0,364 & 0,905 & 0,109 & 0,297 \\
\hline \multirow[t]{2}{*}{ Davranışsal boşverme } & $\mathrm{R}$ & $-0,049$ & $-0,031$ & $-0,083$ & 0,003 & 0,032 & $-0,056$ \\
\hline & $\mathrm{p}$ & 0,709 & 0,814 & 0,530 & 0,979 & 0,806 & 0,673 \\
\hline \multirow[t]{2}{*}{ Zihinsel boşverme } & $\mathrm{r}$ & $-0,069$ & $-0,135$ & $-0,074$ & $-0,092$ & $-0,056$ & $-0,159$ \\
\hline & $\mathrm{p}$ & 0,598 & 0,304 & 0,576 & 0,486 & 0,670 & 0,225 \\
\hline \multirow[t]{2}{*}{ Madde kullanımı } & $\mathrm{r}$ & 0,146 & 0,107 & $0,276^{*}$ & 0,038 & 0,057 & 0,157 \\
\hline & $\mathrm{p}$ & 0,265 & 0,414 & 0,033 & 0,770 & 0,665 & 0,232 \\
\hline Duruma odaklanma & $\mathrm{r}$ & 0,196 & 0,203 & 0,076 & 0,086 & 0,164 & $-0,137$ \\
\hline & $\mathrm{p}$ & 0,133 & 0,119 & 0,565 & 0,514 & 0,209 & 0,297 \\
\hline İnkar & $\mathrm{r}$ & 0,086 & 0,008 & $-0,085$ & 0,136 & 0,082 & 0,183 \\
\hline & $\mathrm{p}$ & 0,513 & 0,949 & 0,519 & 0,301 & 0,533 & 0,162 \\
\hline İşlevsel olmayan başa çıkma & $\mathrm{r}$ & 0,107 & 0,054 & 0,019 & 0,124 & 0,082 & 0,067 \\
\hline & $\mathrm{p}$ & 0,416 & 0,679 & 0,883 & 0,344 & 0,533 & 0,610 \\
\hline Duygusal sosyal destek kullanımı & $\mathrm{r}$ & 0,035 & 0,070 & 0,033 & $-0,072$ & $-0,073$ & 0,204 \\
\hline & $\mathrm{p}$ & 0,790 & 0,595 & 0,800 & 0,586 & 0,577 & 0,119 \\
\hline Pozitif yeniden yorumlama & $\mathrm{r}$ & $-0,323^{*}$ & $-0,454^{* *}$ & $-0,130$ & $-0,246$ & $-0,189$ & $-0,219$ \\
\hline & $\mathrm{p}$ & 0,012 & 0,000 & 0,321 & 0,058 & 0,147 & 0,092 \\
\hline Dini başa çıkma & $\mathrm{r}$ & $-0,076$ & $-0,178$ & $-0,155$ & $-0,077$ & $-0,115$ & 0,182 \\
\hline & $\mathrm{p}$ & 0,564 & 0,175 & 0,237 & 0,560 & 0,380 & 0,163 \\
\hline Kabullenme & $\mathrm{r}$ & $-0,043$ & $-0,086$ & 0,002 & $-0,043$ & $-0,116$ & $-0,068$ \\
\hline & $\mathrm{p}$ & 0,743 & 0,512 & 0,988 & 0,745 & 0,376 & 0,606 \\
\hline Şaka yapma & $\mathrm{r}$ & $-0,071$ & $-0,162$ & $-0,196$ & $-0,023$ & $-0,029$ & $-0,078$ \\
\hline & $\mathrm{p}$ & 0,588 & 0,215 & 0,134 & 0,864 & 0,828 & 0,551 \\
\hline Duygusal odaklı başa çıkma & $\mathrm{r}$ & $-0,154$ & $-0,261^{*}$ & $-0,133$ & $-0,126$ & $-0,138$ & $-0,078$ \\
\hline & $\mathrm{p}$ & 0,239 & 0,044 & 0,310 & 0,337 & 0,295 & 0,552 \\
\hline Aktif başa çıkma & $\mathrm{r}$ & $-0,152$ &,$- 257^{*}$ & $-0,093$ & $-0,147$ & $-0,111$ & 0,015 \\
\hline & $\mathrm{p}$ & 0,246 & 0,047 & 0,478 & 0,262 & 0,400 & 0,907 \\
\hline Planlama & $\mathrm{r}$ & $-0,098$ & $-0,197$ & $-0,116$ & $-0,112$ & $-0,101$ & 0,006 \\
\hline & $\mathrm{p}$ & 0,458 & 0,131 & 0,379 & 0,395 & 0,443 & 0,966 \\
\hline Yararlı sosyal destek kullanımı & $\mathrm{r}$ & 0,131 & 0,187 & 0,031 & $-0,021$ & $-0,076$ & 0,154 \\
\hline & $\mathrm{p}$ & 0,317 & 0,153 & 0,816 & 0,872 & 0,563 & 0,239 \\
\hline Diğer meşguliyetleri bastırma & $\mathrm{r}$ & 0,077 & 0,046 & 0,058 & $-0,133$ & 0,006 & $0,431^{* *}$ \\
\hline & $\mathrm{p}$ & 0,561 & 0,725 & 0,658 & 0,311 & 0,964 & 0,001 \\
\hline Geri durma & $\mathrm{r}$ & $-0,072$ & $-0,048$ & $-0,122$ & $-0,226$ & $-0,061$ & 0,010 \\
\hline & $\mathrm{p}$ & 0,583 & 0,717 & 0,355 & 0,083 & 0,645 & 0,937 \\
\hline Sorun odaklı başa çıkma & $\mathrm{r}$ & $-0,051$ & $-0,086$ & $-0,069$ & $-0,199$ & $-0,129$ & 0,212 \\
\hline & $\mathrm{p}$ & 0,696 & 0,515 & 0,602 & 0,128 & 0,325 & 0,103 \\
\hline
\end{tabular}

r:Spearman rank correlation coefficient, (ÇÇTÖ: Çocukluk çağı travma ölçeği) 
değerlendirildi, modelin anlamlılık sınaması için $\mathrm{p}=0,001$ ve $\mathrm{R}^{2}=\% 26.3$ saptand1. Bipolar bozukluk hastalarında pozitif yeniden yorumlama puanlarındaki bir puan artışın, ÇÇTÖ toplam puanlarında 1,42 puanlık azalma ile ilişkili olduğu görülmüştür $\left(\mathrm{R}^{2}=0,26 ; \mathrm{B}=-1.42, \mathrm{p}=0,008\right)$ (Tablo 8).

Tablo 8. Bipolar Bozukluk Hastalarında Çocukluk Çağı Travma Puanlarının Belirleyicileri Çoklu Doğrusal Regresyon Analizi Sonuçları

\begin{tabular}{|l|c|c|c|c|c|c|}
\hline \multirow{2}{*}{} & \multicolumn{2}{|c|}{} & \multirow{2}{*}{$\begin{array}{c}\text { Standardize olmayan } \\
\text { katsaylar }\end{array}$} & & & \multicolumn{2}{|c|}{ Doğrusallık istatistikleri } \\
\cline { 2 - 3 } & $\mathrm{B}$ & $\mathrm{SE}$ & $\mathrm{t}$ & $\mathrm{P}$ & Tolerans & VIF \\
\cline { 2 - 7 } & 0,701 & 0,393 & 1,782 & 0,080 & 0,888 & 1,126 \\
\hline Kendini suçlama & 0,731 & 0,387 & 1,889 & 0,064 & 0,986 & 1,014 \\
Diğerlerini suçlama & $-1,419$ & 0,519 & $-2,735$ & $0,008^{*}$ & 0,900 & 1,112 \\
\hline
\end{tabular}

(B: regresyon katsayısı, SE: Standart hata) Modelin anlamlılık sınaması için $\mathrm{p}=0,001, \mathrm{R}^{2}=\% 26.3$

Tablo 9. ÇÇTÖ Toplam Puanı $\geq 35$ olan Bipolar Bozukluk Hastalarında Çok Değişkenli Binary Lojistik Regresyon Analizi

\begin{tabular}{|l|c|c|}
\hline & OR[95\% GA] & $\mathrm{p}$ \\
\hline Kendini suçlama & $1,31[1,03-1,67]$ & $0,026^{*}$ \\
\hline $\begin{array}{l}\text { Duygusal odaklı başa } \\
\text { çıma }\end{array}$ & $0,96[0,89-1,04]$ & 0,307 \\
\hline Geri durma & $0,73[0,53-1]$ & 0,051 \\
\hline
\end{tabular}

(OR: odds oranı, GA: Güven aralığı) Modelin anlamlılık sınaması için $\mathrm{p}=0,001$, Nagelkerke $\mathrm{R}^{2}=\% 30$

\section{TARTIŞMA}

Bu çalışmada, remisyonda bipolar bozukluk hastalarında çocukluk çağı travması, bilişsel duygu düzenleme ve başa çıkma tutumları araştırılmıştır. Sonuçlara bakacak olursak, Bipolar bozukluk hastalarının çocukluk çağ travma ölçeği (ÇÇTÖ) ortalama puanı ise 45,82 $\pm 12,97$ idi. Bipolar bozukluk hastalarının \%76,6'sında $(n=46)$ ÇÇTÖ puanı 35 ve üstünde saptandı. Çocukluk çağı travması olan bipolar bozukluk hastalarında, kendini suçlama belirgin olarak yüksek, duygusal odaklı başa çıkma belirgin olarak düşük saptandı. Ayrıca bipolar bozukluk hastalarında çocukluk çağı travması toplam puanı ile kendini suçlama ve diğerlerini suçlama arasında pozitif yönde anlamlı ilişki, olumlu yeniden değerlendirme ve pozitif yeniden yorumlama ile negatif yönde anlamlı ilişki saptandı.

Çocukluk çağındaki travmalar ve stresli yaşam olaylarının bipolar bozukluk gelişimi için yatkınlaştırıcı olabileceği ve erişkin dönemde hastalığın ortaya çıkması için santral sinir sistemini duyarlı hale getirebileceği düşünülmektedir (20). Literatüre bakıldığında genel olarak bipolar bozukluk hastalarında çocukluk çağ travmasının \%45-68 arasında olduğu bildirilmiştir (2123). Garno ve arkadaşlarının yaptığ 1 çalışmada fiziksel ihmal \%12, duygusal istismar \%37, fiziksel istismar \%37, duygusal ihmal \%24 olarak bildirilmiştir (22). Bir başka
ÇÇTÖ toplam puanı 35 ve üzerinde olan hastalar çok değişkenli ikili regresyon analizi ile değerlendirildiği modelde, modelin anlamlılık sınaması için $p=0,001$ ve $\mathrm{R}^{2}: \% 30$ olarak saptandı. Kendini suçlama puanındaki her bir birimlik artışın, ÇÇTÖ toplam puanının 35 ve üzerinde olma ihtimalinde 1,31 kat artış ile ilişkili olduğu görülmüştür ( $\left.\mathrm{R}^{2}=0,339 ; \mathrm{p}=0,026\right)$ (Tablo 9). çalışmada ise bipolar bozukluk hastalarında çocukluk çağ 1 travması \%61,2, travma alt tiplerine bakıldığında ise fiziksel istismar \%25.9, duygusal istismar $\% 26,7$, cinsel istismar \%20,7, fiziksel ya da duygusal ihmal ise \% \%39.7 olarak bulunmuş ve çocukluk çağı travması olan hastalarda daha fazla depresif atak, daha fazla atak sayısı, daha sık intihar girişimi ve daha düşük yaşam kalitesi skorları bildirilmiştir (23). Leverich ve ark. nın 631 bipolar bozukluk hastasını inceledikleri çalışmada ise kadın hastaların \% 49'u, erkek hastaların \%36'sında çocukluk çağı fiziksel ya da cinsel istismar bildirilmiştir (21). Çalışmalarda istismar öyküsü olan hastalarda, erken hastalık başlangıcı, şiddetli manik atak, daha fazla hızlı döngü, daha fazla intihar girişimi, daha fazla depresif atak, daha uzun hastane yatışları ve daha fazla psikiyatrik ek tanı bildirilmiştir $(22,24)$. Bizim çalışmamızda ise bipolar bozukluk hastalarının \%76,6'sında çocukluk çağ 1 travması olduğu saptanmıştır. Çocukluk çağı travma ölçeği skoru 35'in altında olan 14 bipolar bozukluk hastasının 8'inde duygusal istismar, fiziksel istismar, fiziksel ihmal, duygusal ihmal ve cinsel istismardan en az birisinin olduğu düşünüldüğünde çocukluk çağ 1 travması olan hastaların oranı \%90'a ulaşmaktadır.

Bilişsel duygu düzenleme, olumsuz veya olumlu duygusal deneyim ya da ifadeyi, yoğunluğunu ve sıklığını azaltarak veya artırarak düzenleme, sürdürme ve değiştirme için otomatik bir yeteneği ifade eder, kısaca bilişler yoluyla duyguların düzenlenmesidir. Bipolar bozukluk hastaları manik, depresif epizotlar ve epizotlar arasında önemli ölçüde duygulanım dengesizliği ve yoğunluğu yaşamaktadır, emosyon ile ilişkili durumları aşırı uyarma eğiliminde olan uyumsuz duygu düzenleme stratejilerini daha fazla kullanma eğilimindedirler (25). Bir çalışmada bipolar hastalarda sağlıklı kontrollere göre uyumsuz bilişsel duygu düzenleme yöntemleri olan ruminasyon, felaketleştirme ve kendini suçlamanın daha fazla kullanıldığı, uyumlu bilişsel duygu düzenleme yöntemi olan olumlu yeniden değerlendirmenin ise daha az kullanıldığı, felaketleştirme, kendini suçlama ve bilişsel çerçeveleme tekniklerinin bipolar bozukluk için incinebilirlik faktörleri oldukları, ruminasyonun ise 
bipolar bozukluktaki depresif belirtilerin önemli bir yordayıcısı olduğu bildirilmiştir (26). Başka bir çalışmada ise bipolar bozukluk hastalarında sağlıklı kontrollere göre daha sık ruminasyon, felaketleştirme ve kendini suçlama ve daha az olayın değerini azaltma stratejileri kullanımı olduğu, bipolar semptomatolojinin en önemli yordayıcısının artmış ruminasyon ve azalmış olumlu yeniden değerlendirme stratejilerinin kullanımı olduğu bildirilmiştir (27).

Çocukluk çağı travmalarını da içeren erken çocukluk yaşantıları, bireyin duygu düzenleme, bilişsel gelişimi ve başa çıkma becerilerinin oluşumunu etkilemektedir (13). Çocukluk çağı olumsuz yaşam deneyimleri olan kişilerin, erişkinlik döneminde daha uyumsuz duygu düzenleme becerilerine sahip oldukları, uyumsuz duygu düzenleme stratejilerinin yetişkin dönemde psikopatoloji ile daha ilişkili olduğu bildirilmiştir (28). Bizim çalışmamızda, çocukluk çağı travması toplam puanları ile uyumsuz bilişsel duygu düzenleme yöntemlerinden kendini suçlama ve diğerlerini suçlama arasında pozitif yönde anlamlı korelasyon, olumlu yeniden değerlendirme ile negatif yönde anlamlı korelasyon saptanmıştır. Duygusal istismar puanları ile uyumsuz bilişsel duygu düzenleme yöntemlerinden kendini suçlama, ruminasyon ve felaketleştirme ile pozitif yönde anlamlı korelasyon, olumlu yeniden değerlendirme ile negatif yönde anlamlı korelasyon saptanmıştır. Fiziksel istismar puanları ile uyumsuz bilişsel duygu düzenleme yöntemlerinden kendini suçlama ile pozitif yönde anlamlı korelasyon saptanmıştır. Cinsel istismar puanları ile uyumsuz bilişsel duygu düzenleme yöntemlerinden diğerlerini suçlama, ruminasyon ve felaketleştirme ile pozitif yönde anlamlı korelasyon saptanmıştır.

Bipolar bozukluk hastalarında stresli yaşam olaylarının hastalığın gelişiminde, atakların tetiklenmesinde önemli rol oynadığı, bipolar bozukluk hastalarının hastalık nedeniyle daha fazla stresli yaşam olayına maruz kaldığ düşünüldüğünde, kişinin stresli yaşam olaylarına direnmesini sağlayan bireye özgü nitelikteki başa çıkma tutumlarının önemi ortaya çıkmaktadır $(29,30)$ Başa çıkma, kişinin içsel durumu ve çevresel faktörlere duyarlı karmaşık bir süreçtir (31). Uyumsuz başa çıkma stratejileri psikiyatrik hastalıkların klinik seyrini etkilemektedir (32). Bipolar bozukluk hastaları ile yapılan bir çalışmada sürekli anksiyete ve olumsuz değerlendirme korkusunun, adaptif başa çıkma yöntemleri ile negatif korelasyon, benlik saygısının ise pozitif korelasyon gösterdiği bildirilmiştir (33). Bipolar bozukluk hastalarında başa çıkma tutumlarının değerlendirildiği bir çalışmada borderline kişilik bozukluğu eş tanısı olmayan hastaların ortalama olarak sorun odaklı başa çıkma tutumlarından $55,65 \pm 10,24$, duygusal odaklı başa çıkma tutumlarından $55,33 \pm 9,13$, işlevsel olmayan başa çıkma tutumlarından 39,81 \pm 7,43 puan aldıkları bildirilmiştir (34). Bizim çalışmamızda ise hastaların aldıkları ortalama puanlar sırasıyla sorun odaklı başa çıkma tutumlarından $53,63 \pm 9,93$, duygusal odaklı başa çıkma tutumlarından $56,93 \pm 9,74$, işlevsel olmayan başa çıkma tutumlarından $47,43 \pm 9.75$ idi. Ayrıca çocukluk çağı travması toplam puanı ve duygusal istismar puanı ile duygusal odaklı başa çıkma tutumlarından pozitif yeniden yorumlama arasında negatif korelasyon, fiziksel istismar ile işlevsel olmayan başa çıkma tutumlarından madde kullanımı arasında pozitif korelasyon, cinsel istismar puanları ile sorun odaklı başa çıkma tutumlarından diğer meşguliyetleri bastırma arasında pozitif korelasyon saptand.

Çalışmamızın bazı kısıtlılıkları bulunmaktadır. Öncelikle çalışmanın kesitsel bir çalışma olması, yalnızca Bipolar bozukluk tip I hastalarının çalışmaya dahil edilmesi, hastaların geçmiş atak özelliklerinin (psikotik belirtili, peripartum başlangıçlı, hızlı döngülü, karma özellikli, anksiyeteli) değerlendirilmemiş olması, çalışmamızda kontrol grubunun bulunmaması ve çalışmanın özbildirim ölçekleri ile yapılması en önemli kısıtlılıklardır.

Sonuç olarak bipolar bozukluk hastalarında çocukluk çağı travmasının çok sık görüldüğü, bilişsel duygu düzenleme ve başa çıkma becerilerini etkileyebileceği göz önünde bulundurularak, klinisyenler bipolar bozukluk hastalarını çocukluk çağı travması açısından mutlaka değerlendirmelidir. Bipolar bozukluk hastalarında çocukluk çağı travmasının rolünün daha iyi anlaşılabilmesi için geniş hasta grupları ile prospektif, nörogörüntüleme yöntemlerini de içeren çalışmalara ihtiyaç vardır.

Yazarların Katkıları: Fikir/Kavram: T.C.T., O.H.; Tasarım: T.C.T., O.H.; Veri Toplama ve/veya İşleme: T.C.T.; Analiz ve/veya Yorum: T.C.T; Literatür Taraması: T.C.T., O.H.; Makale Yazımı: T.C.T., O.H.; Eleştirel İnceleme: T.C.T.

\section{KAYNAKLAR}

1. Diagnostic and Statistical Manual of Mental Disorders: DSM-5TM. 5th ed. American Psychiatric Publishing, Inc.;2013.

2. Vieta E, Berk M, Schulze TG, Carvalho AF, Suppes T, Calabrese JR, et al. Bipolar disorders. Nat Rev Dis Primers. 2018; 4: 18008.

3. Misiak B, Stramecki F, Gaweda L, Prochwicz K, Sasiadek MM, Moustafa AA, et al. Interactions between variation in candidate genes and environmental factors in the etiology of schizophrenia and bipolar disorder: a systematic review. Mol Neurobiol. 2018; 55(6): 5075-100.

4. Jangam K, Muralidharan K, Tansa KA, Aravind Raj E, Bhowmick P. Incidence of childhood abuse among women with psychiatric disorders compared with healthy women: Data from a tertiary care centre in India. Child Abuse Negl. 2015; 50: 67-75.

5. Turla A. Çocuk istismarı ve ihmali olgularında tıbbi yaklaşım. Ondokuz Mayıs Üniversitesi Tıp Dergisi. 2002; 19(4): 291-300.

6. Yurdakök K, İnce O. Duygusal istismar ve ihmal. Katk1 Pediatri Dergisi. 2010; 32(4): 423-33.

7. Heim C, Nemeroff CB. The impact of early adverse experiences on brain systems involved in the pathophysiology of anxiety and affective disorders. Biol Psychiatry. 1999; 46(11): 1509-22.

8. Holtzman CW, Trotman HD, Goulding SM, Ryan AT, Macdonald AD, Shapiro DI, et al. Stress and neurodevelopmental processes in the emergence of psychosis. Neuroscience. 2013; 249: 172-91.

9. Belsky J. Attachment, mating, and parenting. Hum Nat. 1997; 8(4): 361-81.

10. Folkman S, Moskowitz JT. Coping: pitfalls and promise. Annu Rev Psychol 2004; 55: 745-74. 
11. Carver CS, Scheier MF, Weintraub JK. Assessing coping strategies: A theoretically based approach. J Pers Soc Psychol. 1989; 56(2): 267-83.

12. Lazarus RS, Cohen JB, Folkman S, Kanver ASC. Psychological stress and adaptation. Some unresolved issues. In: H. Selye, editor. Selye's guide to stress research. New York, NY: Von Nostrand Reinhold; 1980. p. $90-117$.

13. Garnefski N, Kraaij V, Spinhoven P. Negative life events, cognitive emotion egulation and depression. Pers Individ Di. 2001; 30(8): 1311-27.

14. Bernstein DP, Stein JA, Newcomb MD, Walker E, Pogge D, Ahluvalia T, et al. Development and validation of a brief screening version of the Childhood Trauma Questionnaire. Child Abuse Negl. 2003; 27(2): 169-90.

15. Sar V, Öztürk E, Ikikardes E. Cocukluk Cagi Ruhsal Travma Ölceginin Türkce uyarlamasinin gecerlilik ve güvenilirligi. Turkiye Klinikleri J Med Sci. 2012; 32(4): 1054-63.

16. Carver CS, Scheier MF, Weintraub JK. Assessing coping strategies: A theoretically based approach. Journal of Personality and Social Psychology. 1989; 56(2): 267-83.

17. Ağargün MY, Beşiroğlu L, Kıran ÜK, Özer ÖA, Kara H. COPE (Başa çıkma tutumlarını değerlendirme ölçeği): Psikometrik özelliklere ilişkin bir ön çalışma. Anatolian Journal of Psychiatry. 2005; 6(4): 221-6.

18. Garnefski N, Kraaij V, Spinhoven P. CERQ: Manual for the use of the cognitive emotion regulation Questionnaire. Leiderdorp, the Netherlands: DATEC V.O.F; 2002.

19. Ataman Temizel E, Dağ İ. Relationships among stressful life events, cognitive emotion regulation strategies, depressive symptoms and anxiety levels. Klinik Psikiyatri. 2014; 17(1): 7-17.

20. Heim C, Nemeroff CB. The role of childhood trauma in the neorobiology of mood and anxiety disorders: ptrcilinical and clinical studies. Biol Psychiatry. 2001; 49(12): 1023-39.

21. Leverich GS, McElroy SL, Suppes T, Keck PE, Denicoff KD, Nolen WA, et.al. Early physical and sexual abuse associated with an adverse course of bipolar illness. Biol Psychiatry. 2002; 51(4): 288-97.

22. Garno JL, Goldberg JF, Ramirez PM, Ritzler BA. Impact of childhood abuse on clinical course of bipolar disorder. Br J Psychiatry. 2005; 186(2); 121-5.

23. Erten E, Uney Kalkay AF, Saatçioğlu Ö, Özdemir A, Fıstıkçı N, Çakmak D. Effects of childhood trauma and clinical features on determining quality of life in patients with bipolar disorder. J Affect Disord. 2014; 162: 107-13.

24. Hyun M, Friedman SD, Dunner DL. Relationship of childhood physical and sexual abuse to adult bipolar disorder. Bipolar Disord. 2000; 2(2): 131-5.

25. Dodd A, Lockwood E, Mansell W, Palmier-Claus J. Emotion regulation strategies in bipolar disorder: a systematic and critical review. J Affect Disord. 2019; 246: 262-84.

26. Green MJ, Lino BJ, Hwang E-J, Sparks A, James C, Mitchell PB. Cognitive regulation of emotion in bipolar I disorder and unaffected biological relatives. Acta Psychiatr Scand. 2011: 124(4): 307-16.
27. Rowland JE, Hamilton MK, Lino BJ, Ly P, Denny K, Hwang EJ, et al. Cognitive regulation of negative affect in schizophrenia and bipolar disorder. Psychiatry Res. 2013; 208(1): 21-8.

28. Eisenberg N, Fabes RA. Emotion and its regulation in early development: New directions for child development. San Francisco: Jossey- Bass; 1992.

29. Hall K, Dunner DL, Zeller G, Fieve RR. Bipolar illness: a prospective study of life events. Comp Psychiatry. 1977; 18(5): 497-502.

30. Ak M, Lapsekili N, Hacıömeroğlu B, Sütçügil L, Türkçapar H. Early maladaptive schemas in bipolar disorder. Psychol Psychother. 2012; 85(3): 260-7.

31. Folkman S, Moskowitz JT. Coping: pitfalls and promise. Annual Review of Psychology. 2004; 55: 745-74.

32. Parikh SV, Velyvis V, Yatham L, Beaulieu S, Cervantes P, Macqueen G, et al. Coping styles in prodromes of bipolar mania. Bipolar Disorders. 2007; 9(6): 589-95.

33. Coulston CM, Bargh DM, Tanious M, Cashman EL, Tufrey K, Curran G. Is coping a well matter of personality? A study of euthymic unipolar and bipolar patients. J Affect Disord. 2013; 145(1): 54-61.

34. Usta H, Güleç H, Hariri AG, Yazıcı Güleç M. The effect of cluster B personality disorder comorbidity on the coping styles in patient with bipolar disorder. Anadolu Psikiyatri Dergisi. 2015; 16(4): 247-54. 